\title{
Humusbalans i odlad jord
}

\author{
JAN PERSSON \\ Lantbrukshögskolan, Institutionen för markvetenskap, avdelningen för \\ växtnäringslära, 75007 Uppsala 7, Sverige.
}

\section{Humus balance in cultivated soil}

\section{Jan Persson}

Department of Soil Sciences, Agricultural College of Sweden, 75007 Uppsala 7, Sweden.

\begin{abstract}
Studies of the organic content and biological activity of the soil have been made on two farms belonging to the Agricultural College of Sweden. The soil analyses on the two farms were compiled during the 1930's, and the samples taken at the time, as well as the maps used during the sampling, have been preserved. Some parts of the farms were again sampled in the early 1970's. The samples from the two series have been analysed for organic carbon. In some of the samples the biological activity was determined in incubation experiments and the organic matter was frac-
\end{abstract} tionated.

The areas chosen for the investigation represent different soil types and have different cropping backgrounds. Some of them have been cultivated for several hundred years while others have only recently been brought under the plough.

The determinations of organic carbon show that the humus content in the recently broken soils decreased considerably during the 40 years separating the samplings. The magnitude of the decrease partly depends on the extent of the decomposition at the first sampling, partly on the moisture conditions.

In some cases decreases of the humus content were also registered in the older fields. This may be due to intensified soil cultivations and improved drainage.

The amount of easily decomposable substances in the initial samples was larger than in the later ones. This difference may be partly due to changes taking place during storage, and the results suggest that to some extent it may also depend on a higher biological activity in the soil at the initial sampling.

\section{Bakgrund}

Vid Lantbrukshögskolan i Sverige har ett unikt tillfälle erbjudits för belysning av odlingsåtgärdernas betydelse för humusbalansen. Allt sedan högskolan grundades år 1932 har två gårdar, Ultuna och. Kungsängen stått till förfogande för demonstrationer och fältförsöksverksamhet. Under åren närmast efter högskolans tillkomst genomfördes en noggrann markkartering av de 
båda egendomarna. Jordprover uttogs under åren 1935-1939 och markkarteringskartor jämte beskrivning publicerades år 1941 (ToRsTENsson och ERIKSSON 1941).

Sedan jordproverna analyserats arkiverades de och har, frånsett några prover, som vattenskadats, arkiverats torrt i slutna påsar. Också de kartor, som låg till grund för provtagningarna finns bevarade. Med ledning av dessa kartor har provtagningen upprepats på några arealer. Denna provtagning utfördes under åren $1970-1972$.

Jordproverna har underkastats kolanalys. I viss omfattning har också inkubationsförsök och fraktioneringsförsök utförts. Samtliga jordprover, som ingått i undersökningen har analyserats i anslutning till sista provtagningstillfället - således även proverna från det första provtagningstillfället.

\section{Nagot om jordarnas ursprung och sammansättning}

Området, som varit föremål för undersökningen ligger under högsta kustlinjen och jordarna består mestadels av sedimenterade leror. På Ultuna går en kalkhaltig glaciallera i dagen på vissa stråk. I allmänhet är emellertid glacialleran överlagrad av postglacial lera, som inte är kalkhaltig. På en stor del av gårdens areal är lerorna påverkade av material, som svallats ut dels från en rullstensås dels från kringliggande moränområden. Detta gör att jordarna på Ultuna är mycket varierande.

På Kungsängen utgöres de lösa jordavlagringarna av postglaciala sediment, vilka har en mycket stor mäktighet. Längs Fyrisån, som flyter i områdets ytterområde finns svämleror. Jordarten är mycket homogen och utgöres huvudsakligen av styv lera.

\section{Kort om odlingshistorien}

Som boplats är Ultuna mycket gammalt. Gravar från trakten har daterats till 700-talet. Tidigt blev kyrkan ägare av större delen av Ultunajorden. På 1500-talet övertogs jorden av kronan och omkring år 1610 inrättades en kungsladugård på Ultuna. En karta från 1630-talet visar att en stor del av nuvarande åkerareal odlades redan då. På 1850-talet började man täckdika åkrarna. Detta arbete var färdigt omkring år 1880. Tidigare dränerades fälten via ett stort antal öppna diken.

Vid olika tillfällen har ett antal torp och mindre egendomar införlivats med Ultuna. En sådan egendom är Hammarby, som arrenderades av Ultuna fr.o.m. år 1930 och som senare förvärvats av högskolan.

Kungsängen har en mycket yngre odlingshistoria. Gården, som ligger lägre än Ultuna stod fortfarande under vatten när bebyggelse började etableras på Ultuna. När kungsladugården grundlades vid Ultuna omkring år 1610 började man utnyttja Kungsängen som slåtteräng. Den var emellertid då mycket försumpad och den stod under vatten på vårarna. Ännu i mitten av 1850-talet låg endast en liten del av Kungsängen under plog. År 1854 påbörjades emellertid nyodling av ängsmarkerna och i slutet av 1860-talet var Kungsän- 
gen uppodlad utom de områden, som ligger närmast Fyrisån, vilka var alltför sanka. Dessa har till större delen uppodlats under 1900-talet. En del av Kungsängen har aldrig plöjts. Denna del, som utgör ett naturreservat för att skydda Kungsängsliljan, utnyttjas i dag som bete. Till Kungsängen hör också de s.k. Hovstallängarna, som också under lång tid använts som ängsmark. Uppodling av dessa marker torde ha skett med början omkring år 1880 .

\section{Utvalda arealer för undersökningen}

Strävan var att för undersökningen välja arealer, som skiljer sig från varandra med avseende på odlingshistoria. Som framgår av föregående avsnitt erbjuder de båda gårdarna ett gott urval härvidlag. Av skilda anledningar har dock valmöjligheterna i viss mån begränsats. Således undveks de delar på Ultuna, där den karbonathaltiga glacialleran går i dagen; detta för att slippa ifrån störningar från karbonatet vid bestämning av organiskt kol. Vidare har urvalet av arealer begränsats av att vissa delar bebyggts sedan den första provtagningen gjordes på 1930-talet. Detta gäller framför allt på Ultuna men även på Kungsängen har en del mark tagits ur odling av detta skäl. Således har det, p.g.a. vägbygge, inte varit möjligt att i undersökningen ta med de områden av Kungsängen, som var uppodlade redan innan den stora nyodlingen påbörjades år 1854 .

På Ultuna uttogs skiftena Hammarby V, Hammarby VI samt Jälbo. Av dessa arealer hör förmodligen Hammarby VI och Jälbo till de delar, som längst varit i odling. Detta kan man sluta sig till av Torstenssons och Erikssons kartor. Dessa visar att fosfortillståndet är mycket gott här. Det är en vanlig företeelse att fosfortillståndet är gott på de åkrar som ligger närmast bebyggelsen och som länge använts i öppen odling. Dessa påfördes nämligen all stallgödsel, som producerats med hjälp av foder som tagits från längre bort belägen ängsmark. Den tidigare omtalade kartan från 1630-talet omfattar inte Hammarby, men det framgår att Jälbo var uppodlat redan då.

På Kungsängen utvaldes delar av fyra skiften med olika odlingshistoria: Skifte I, Ängen, Hovstallängarna och Reservatet. Skifte I hör till den del av Kungsängen, som odlades upp under perioden $1854-1870$, förmodligen under förra delen av perioden. Odlingshistorien för Hovstallängarna är något höljd i dunkel. Enligt muntliga uppgifter som erhållits påbörjades uppodlingen av dessa marker på 1880-talet. Ängen ligger på de områden längs Fyrisån som var allför vattensjuka för att de skulle kunna odlas upp i samband med nyodlingen på 1800-talet. Uppodlingen skedde förmodligen först på 1920-talet. Reservatet slutligen har, som tidigare omtalats, aldrig varit plöjt. De olika arealernas läge framgår av Figurerna 1 och 2.

\section{Metodik}

Provtagning. Till grund för provtagningarna har legat ett rutnät, som uppgjordes vid den första karteringen 1935-1939. På Ultuna gjordes provtagningarna i kvadratförband med $25 \mathrm{~m}$ sida. På Kungsängen, där jor- 


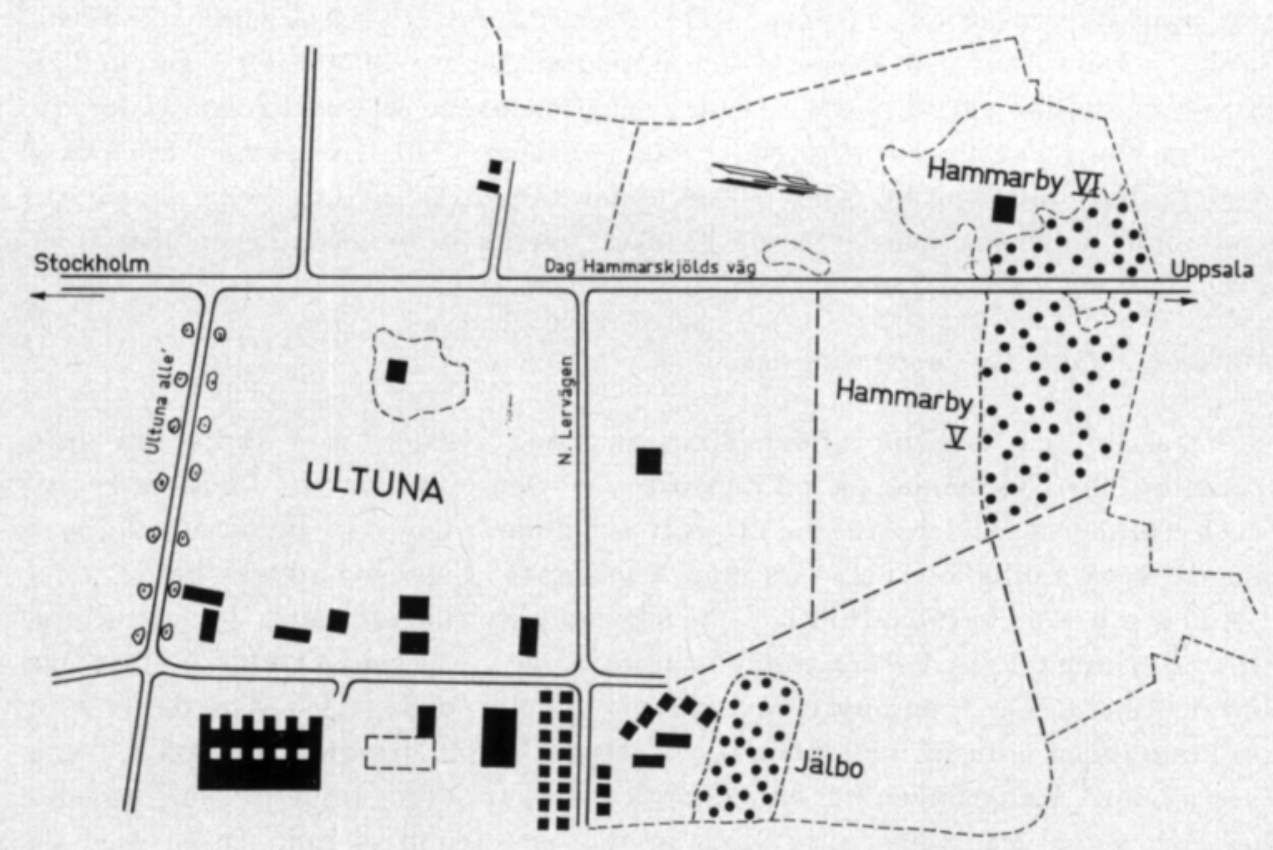

Figur 1. Försöksarealernas placering på Ultuna.

Fig. 1. The location of the sampling sites at Ultuna.

den är jämnare gjordes provtagningen glesare - kvadratförband med $50 \mathrm{~m}$ sida. Kontrollmätningar visade att provtagningsplatserna kunde återfinnas vid den sista provtagningen på någon meter när.

Provtagningen vid den första karteringen skedde med spade. Någon närmare beskrivning av tillvägagångssättet finns inte redovisad. Vid omkarteringen gjordes provtagningen medelst jordborr. Därvid uttogs inom en radie av $3 \mathrm{~m} 10$ stycken borrkärnor till $20 \mathrm{~cm}$ djup.

Prover uttagna vid den första karteringen kommer i fortsättningen att hänföras till år 1941 (årtalet för publiceringen). Prover uttagna vid den sista karteringen hänföres till år 1970.

Provpreparering. Efter uttagning i fält torkades proverna varefter de maldes så att jorden passerade en $2 \mathrm{~mm}$ sikt. Den malda jorden blandades, varefter ca $200 \mathrm{~g}$ uttogs för undersökningen.

För kolanalys uttogs ett delprov om ca $20 \mathrm{~g}$, som homogeniserades ytterligare genom att det mortlades under 15 minuter. Av detta väl homogeniserade prov uttogs prover för analyserna. Genomgående har parallellanalyser utförts. Denna omsorgsfulla provpreparering har visat sig nödvändig för att man skall erhålla godtagbara resultat av kolanalyserna (PERsson 1972).

Prover, som uttogs för inkubationsförsök mortlades så att de passerade $0,6 \mathrm{~mm}$ sikt.

A n a 1 y s. Kolanalysen utfördes medelst våtförbränningsmetoden enligt Jansson och ValdmaA (1961). 


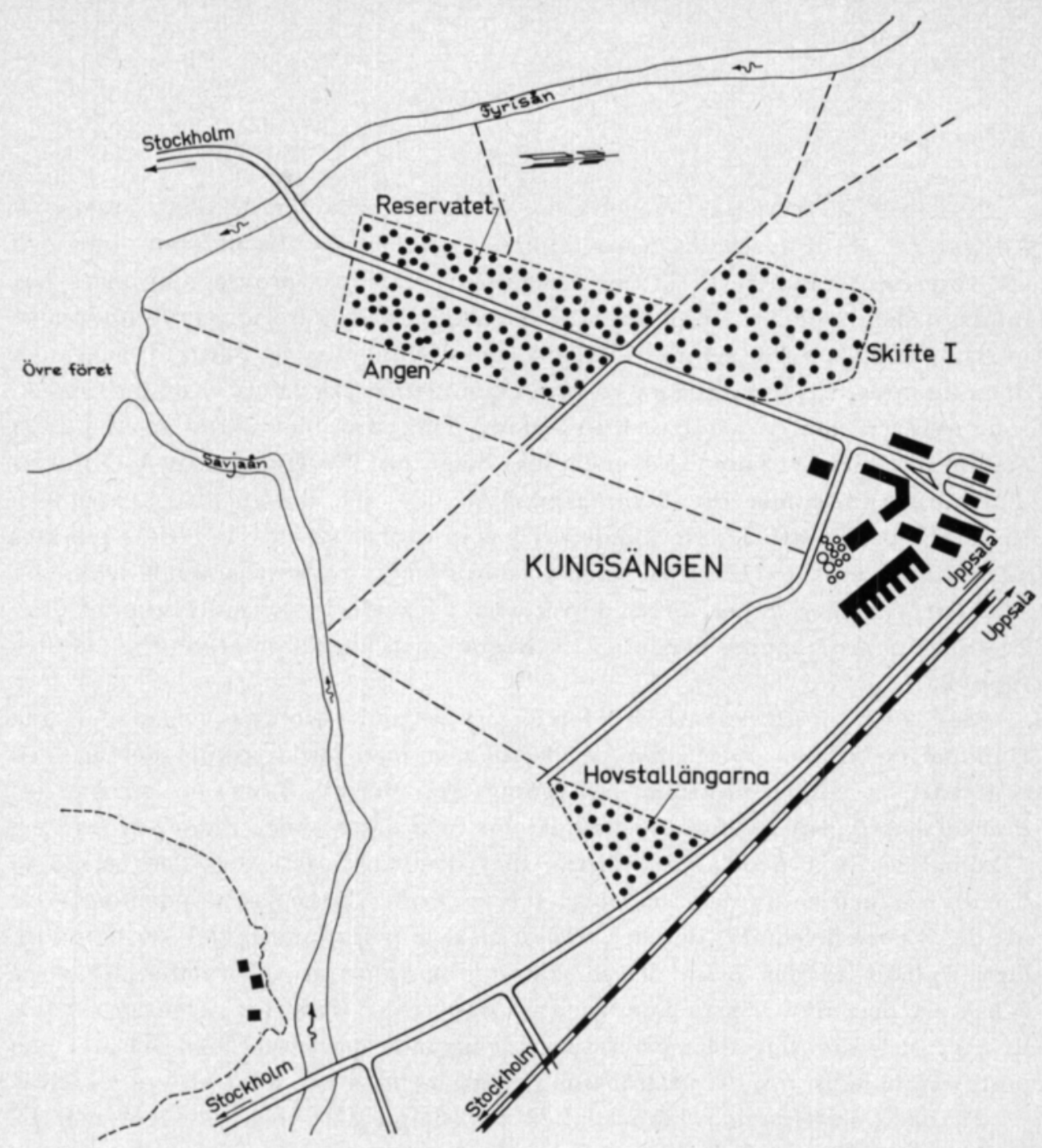

Figur 2. Försöksarealernas placering på Kungsängen.

Fig. 2. The location of the sampling sites at Kungsängen.

$\mathrm{O}$ m s ä t t n i n g s f ö r s ö k. Den biologiska aktiviteten hos jorden bestämdes genom att mäta koldioxidutvecklingen under kontrollerade betingelser. Jorden - $50 \mathrm{~g}$ av varje prov - tillfördes vatten motsvarande $40 \%$ av vattenhållande förmågan varefter den inkuberades vid $22^{\circ}$ under kontinuerlig genomluftning. Utvecklad koldioxid uppsamlades i NaOH-lösning och bestämdes genom titrering. Försöket pågick under 40 dagar.

Fraktionering. Den organiska substansen fraktionerades genom successiv extraktion. I tur och ordning behandlades jorden med kall $0,5-\mathrm{N}$ $\mathrm{H}_{2} \mathrm{SO}_{4}$, varm $0,5-\mathrm{N} \mathrm{H}_{2} \mathrm{SO}_{4}$, varm 3,5- $\mathrm{N} \mathrm{H}_{2} \mathrm{SO}_{4}, 25-\mathrm{N} \mathrm{H}_{2} \mathrm{SO}_{4}$ samt varm $0,5-\mathrm{N}$ $\mathrm{NaOH}$-lösning. Ur NaOH-extraktet isolerades en humussyra-fraktion. Detaljerad beskrivning av extraktionsförfarandet redovisas av PERSson (1968). 


\section{Resultat}

Kolanalyser

I Tabell 1 redovisas medeltalen av kolhalterna för de olika arealerna. I Figurerna 3-8 har kolhalterna införts i tredimensionella diagram, vart och ett respresenterande ett skifte. Kolhalten för varje provtagningsplats har införts i diagrammen. Man får således en direkt jämförelse punkt för punkt mellan de båda provtagningstillfällena. För Kungsängen, Skifte I har inget diagram uppgjorts beroende på att provtagning undveks på ett växtföljdsförsök, som ligger på skiftet i fråga. Provtagningspunkterna blev därför så utspridda att det inte gick att göra ett överskådligt diagram. För Hammarby V omfattar diagrammet inte alla provtagningspunkter. På det skiftet uttogs nämligen så många prover att de inte kunde prickas in i ett diagram. För vissa punkter saknas analys på 1941 års prover beroende på att proverna kommit bort eller skadats. Vid beräkning av medelvärdena i Tabell 1 har motsvarande prov av 1970 års provtagning uteslutits. I diagrammen har däremot samtliga värden inprickats.

Man kan konstatera att det föreligger skillnad i kolhalt mellan de båda Hammarbyskiftena. Detta har emellertid mer med jordartsskillnader än med skillnader i odlingsinriktning att göra. Hammarby $\mathrm{V}$ är jordartsmässigt mycket heterogent. Utöver medeltalet för hela detta skifte redovisas i Tabell 1 kolhalten för två delar av skiftet, dels den västligaste dels den östligaste delen. Var och en av dessa delar är $100 \mathrm{~m}$ breda. En sådan uppdelning visar att den västra delen, dvs den del, som gränsar mot Hammarby VI har betydligt lägre kolhalt än den östra delen. Detaljgranskning av siffermaterialet visar också att den allra högsta humushalten finns i den sydöstra delen av skiftet, dvs den del, som ligger längst ifrån kringliggande moränområden och där den postglaciala leran i minst utsträckning spätts ut med utsvallat grövre material.

På båda skiftena har humushalten i medeltal gått ned - något mer på Hammarby VI än på Hammarby V. En t-test visar att medeltalen för de

Tabell 1. Halten organiskt kol pá de olika arealerna. Medeltal av samtliga analyser.

Table 1. The content of organic carbon in the different fields. Means of all analyses.

\begin{tabular}{|c|c|c|c|c|}
\hline Gârd & Areal & 1941 & 1970 & t-test $\left.{ }^{1}\right)$ \\
\hline \multirow[t]{5}{*}{ Ultuna } & Hammarby $V$, hela skiftet ................... & 1.91 & 1.81 & * \\
\hline & västra delen $. . . \ldots \ldots \ldots \ldots . .$. & 1.59 & 1.63 & \\
\hline &,$\quad$ östra delen $. . . \ldots \ldots \ldots \ldots . . . .$. & 2.20 & 1.99 & $*$ \\
\hline & Hammarby VI .............................. & 1.63 & 1.47 & $*$ \\
\hline & Jälbo ............................................... & 1.91 & 2.00 & \\
\hline \multirow[t]{4}{*}{ Kungsängen } & Skifte I ....................................... & 2.60 & 2.33 & * \\
\hline & 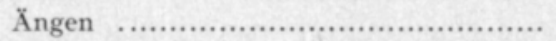 & 2.72 & 2.50 & $*$ \\
\hline & Hovstallängarna ............................. & 3.32 & 2.56 & * \\
\hline & Reservatet .................................... & 3.67 & 3.88 & \\
\hline
\end{tabular}

1) * anger signifikans på $95 \%$-nivàn. 


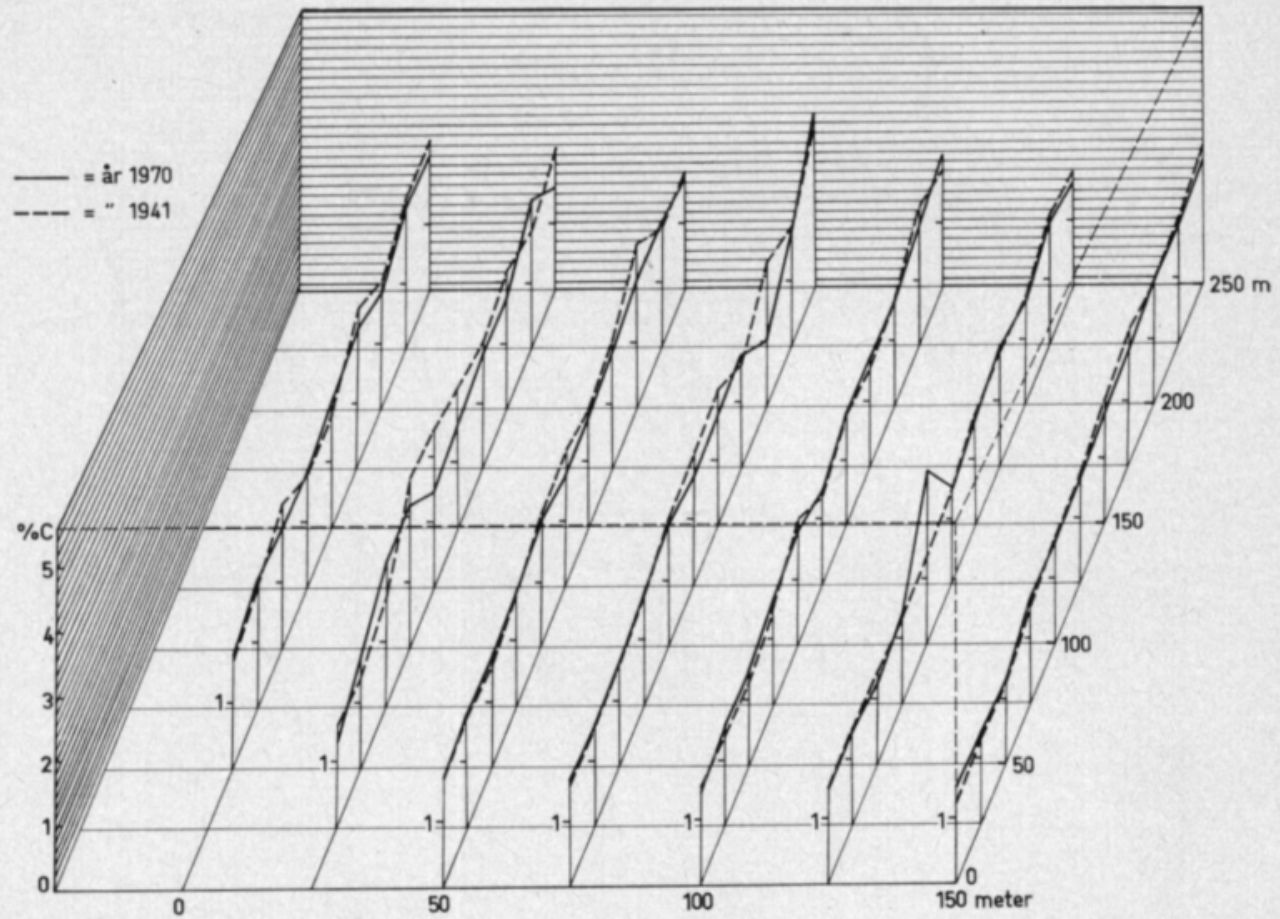

Figur 3. Kolhaltens förändring med tiden i de olika provtagningspunkterna på Hammarby $\mathrm{V}$ (endast en del av den provtagna arealen har medtagits).

Fig. 3. Changes of carbon content at the various sampling sites in field Hammarby $V$ )only part of the sampled area given here).

båda provtagningstillfällena är statistiskt signifikant skilda från varandra. Figurerna 3-4 visar att av linjerna, som representerar kolhalterna, 1970 års linje ganska konsekvent ligger under 1941 års linje för Hammarby VI. Däremot skär kurvorna varandra ganska ofta för Hammarby V.

Utbrytningen av vissa delar av Hammarby $\mathrm{V}$, visar att humushaltsminskningen på skiftet gått olika snabbt på olika delar. På den västra delen kan man överhuvudtaget inte konstatera någon minskning medan den är ganska betydande på den östra delen, där humushalten är högst.

Den sänkning av humushalten, som således konstaterats, kan bero antingen på nettomineralisering av den organiska substansen eller på att plöjningsdjupet ökats någon gång under tiden mellan de båda provtagningarna, vilket leder till att humusförrådet utspädes med humusfattig alv. Det faktum, att en del av den provtagna arealen - den västra delen av Hammarby $\mathrm{V}$ - visar oförändrad humushalt, ger anvisning om att det till stor del är fråga om nettomineralisering. Om man ökat plöjningsdjupet torde detta ha gjorts över hela arealen, alltså även på den västra delen av Hammarby V, som då också skulle ha drabbats av humushaltsminskning. Det synes således som om man haft en mullhaltsminskning som till stor del beror på nettomineralisering på vissa delar, medan humushalten stabiliserat sig på andra delar. Anledningen till att jämviktsinställelsen gått långsammare på vissa delar är svårt att säga någonting 


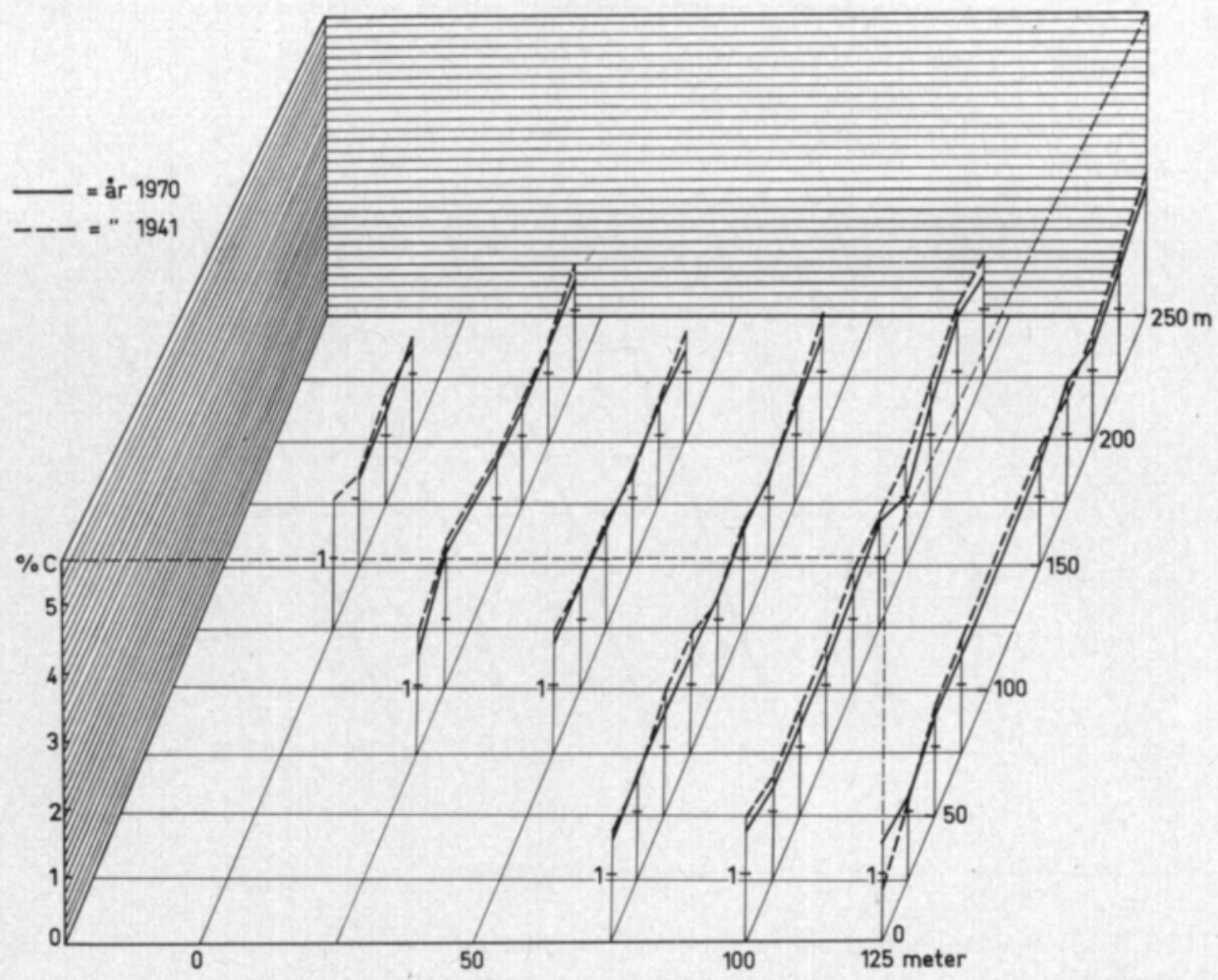

Figur 4. Kolhaltens förändring med tiden i de olika provtagningspunkterna på Hammarby VI. Fig. 4. Changes of carbon content at the various sampling sites in field Hammarby VI.

om. Det kan framhållas att växtodlingen inte varit rovdriftsbetonad. Vallandelen har varit $20-30 \%$ - något högre på Hammarby $\mathrm{V}$ än på Hammarby VI - och stallgödsel har givits i normal omfattning.

På Jälbo finns en tendens till att humushalten ökat de senaste 30 åren. Ökningen är dock inte statistiskt signifikant. Under en 10-årsperiod av den tid undersökningen omfattar låg detta skifte $\mathrm{i}$ betesvall. Detta har naturligtvis verkat hämmande på humusomsättningen, men det är tveksamt, om det kan ha förorsakat en humushaltshöjning, som består 20 år efter det att vallen plöjts upp. Kolhalten på detta skifte ligger i nivå med halten på den östra delen av Hammarby $\mathrm{V}$, alltså betydligt högre än genomsnittet på de båda Hammarbyskiftena.

Humushaltsförändringarna är större på Kungsängen än på Ultuna. På Skifte I har kolhalten gått ned med 0,3 procentenheter trots att marken varit $\mathrm{i}$ odling inemot 100 år när första provtagningen gjordes. Ängen har högre kolhalt vid båda provtagningstillfällena och minskningen är mindre där. Den högre kolhalten kan delvis förklaras av att Ängen uppodlades senare - först en bit in på 1900-talet. Viktigare torde emellertid vara att Ängen alltid varit fuktigare än Skifte I, varför humushaltens jämviktsläge kan förmodas ligga högre. Detta torde också vara den viktigaste förklaringen till att humushaltssänkningen är måttlig jämfört med Skifte I. Växtföljdsskillnader mellan 
provtagningstillfällena kan nämligen inte förklara skillnaden i humushushållningen - vallandelen har varit ungefär lika stor på båda skiftena. Reservation måste göras för att humushaltsminskningen delvis kan bero på att plöjningsdjupet ökats någon gång efter den första provtagningen.

På Hovstallängarna är kolhalten högre än på Skifte I och Ängen. Detta gäller båda provtagningstillfällena. Från det ena provtagningtillfället till det andra har kolhalten sjunkit mycket kraftigt. På samtliga provtagningspunkter är den uppmätta kolhalten lägre vid 1970 års provtagning (Figur 7). Mest märkligt är kanske att humushalten var så hög vid första provtagningstillfället. Uppodlingen skedde på 1880-talet, men det har inte gått att erhålla några detaljerade uppgifter om odlingshistorien före 1940. Den höga humushalten vid första provtagningen kan ha sin förklaring antingen i att arealen till stor del legat i vall från uppodlingen och fram till 1930-talet eller i att marken delvis varit försumpad. En förändring av dessa betingelser har lett till att den organiska substansen blivit föremål för en snabb nedbrytning under de 30 år som ligger mellan de båda provtagningarna. Man har anledning förvänta sig att denna nedbrytning fortsätter ännu en tid såvida inte växtodlingen radikalt omlägges exempelvis genom att permanent vall anlägges. Det finns nämligen inget rimligt skäl till att humushalten skall inta ett högre jämviktsläge

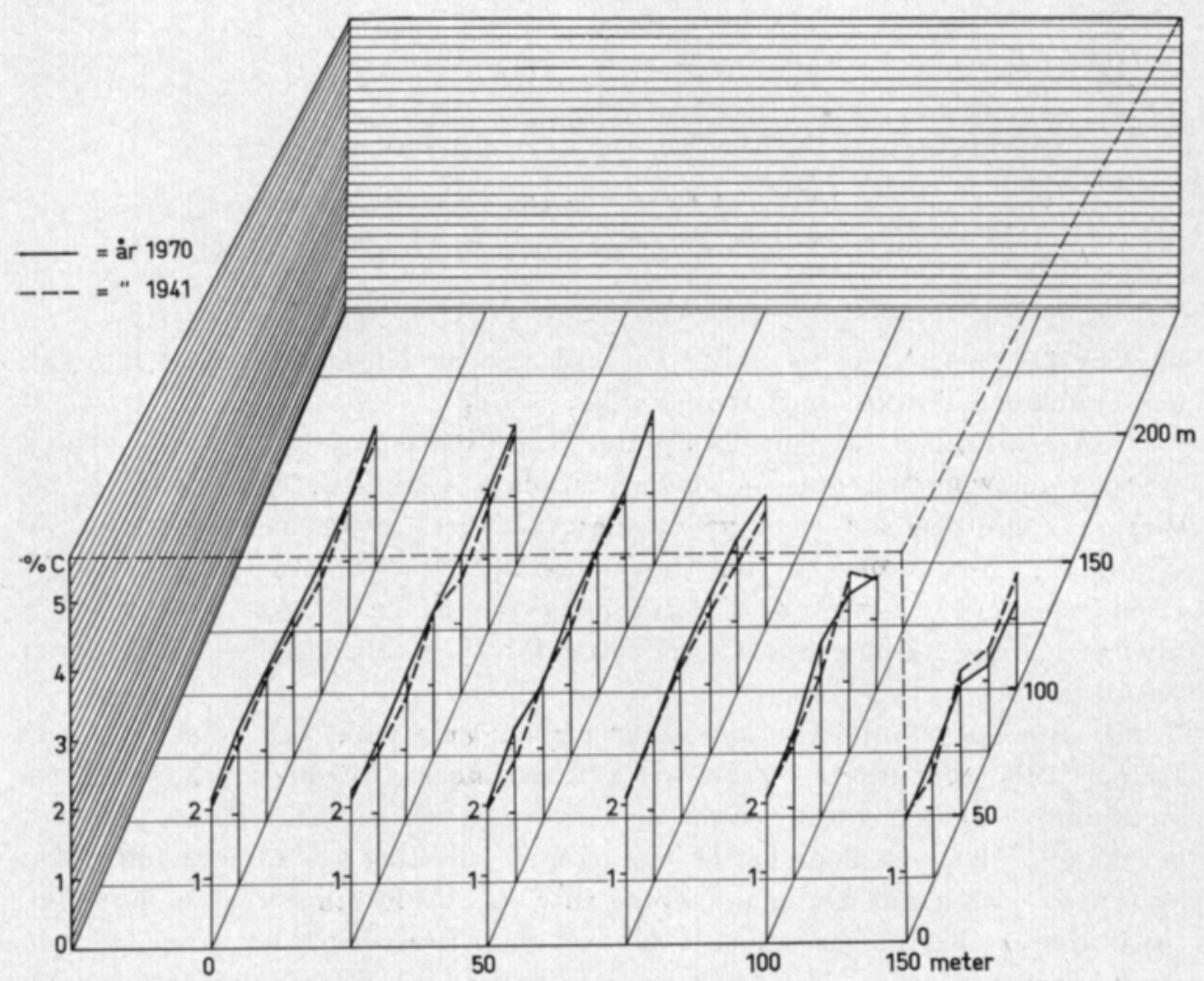

Figur 5. Kolhaltens förändring med tiden i de olika provtagningspunkterna på Jälbo. Fig. 5. Changes of carbon content at the various sampling sites in field Jälbo. 


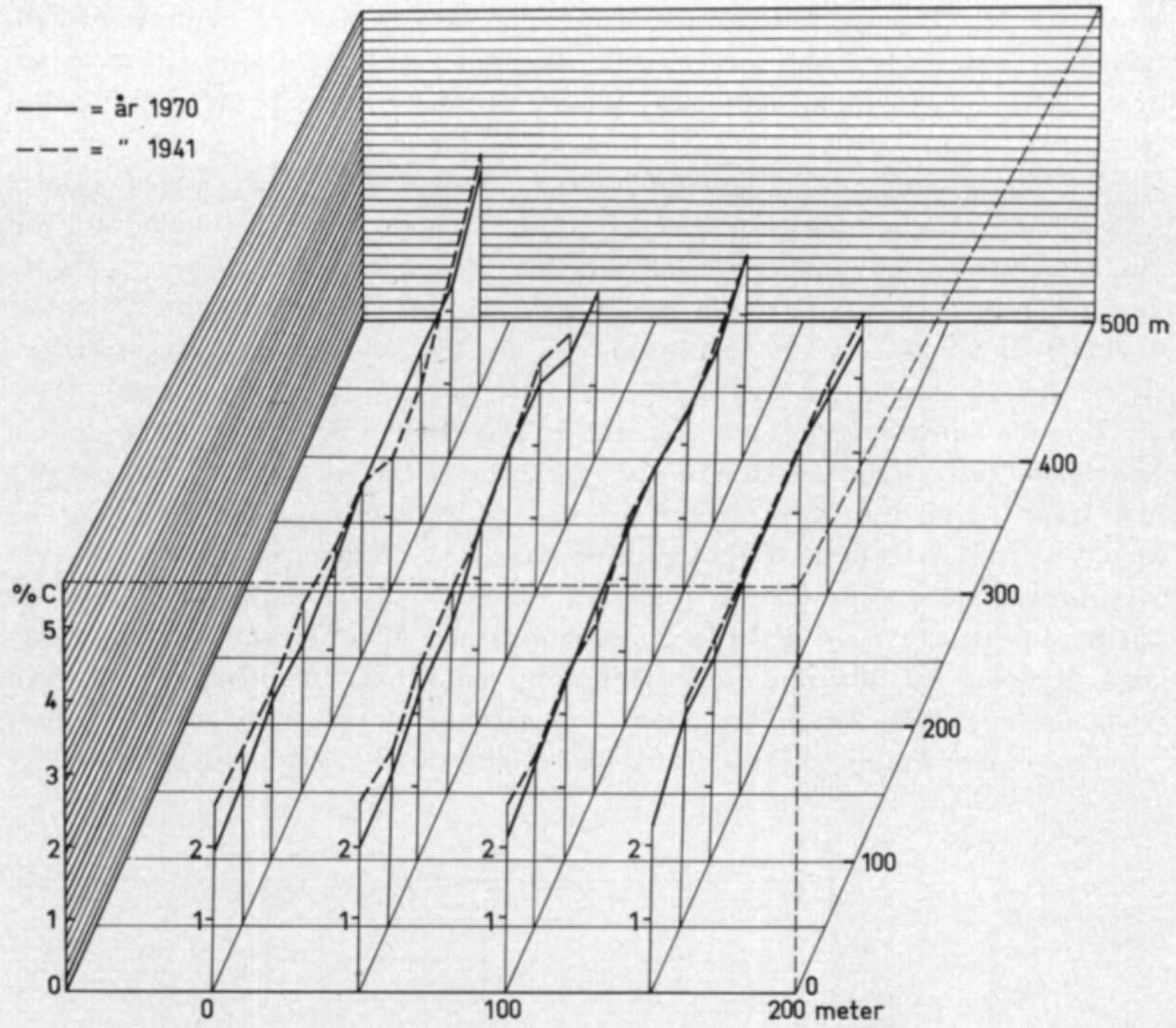

Figur 6. Kolhaltens förändring med tiden i de olika provtagningspunkterna på Ängen. Fig. 6. Changes of carbon content at the various sampling sites in field Angen.

på Hovstallängarna, än på Skifte I. Jordarten är densamma, likaså klimatet och skillnaden i växtodling är obetydlig.

Odlingshistoriskt avviker Reservatet från övriga provtagna arealer genom att den ursprungliga gräs - örtvegetationen aldrig brutits. Kolhalten är snarare högre vid det sista provtagningstillfället. Skillnaden är dock inte signifikant. Figur 8 visar att variationen från provtagningsplats till provtagningsplats är betydande. Detta beror på att de uttagna proverna blir mycket heterogena på grund av att rötter från den täta växtligheten kommer med i provet.

En intressant jämförelse kan göras mellan Reservatet och Ängen vad beträffar 1941 års prover. Trots att skiftena ligger alldeles $\mathrm{i}$ anslutning till varandra - endast vägen skiljer dem åt - är skillnaden i kolhalt mycket betydande. Denna skillnad måste bero på mineralisering som följd av uppodling av Ängen. Eftersom denna uppodling inte skedde förrän en bit in på 1900talet måste minskningen ha gått mycket snabbt under tiden fram till den första provtagningen. Det förhåller sig tydligen så att mineraliseringen av humussubstanserna går mycket snabbt under de första årtiondena efter uppodlingen. 


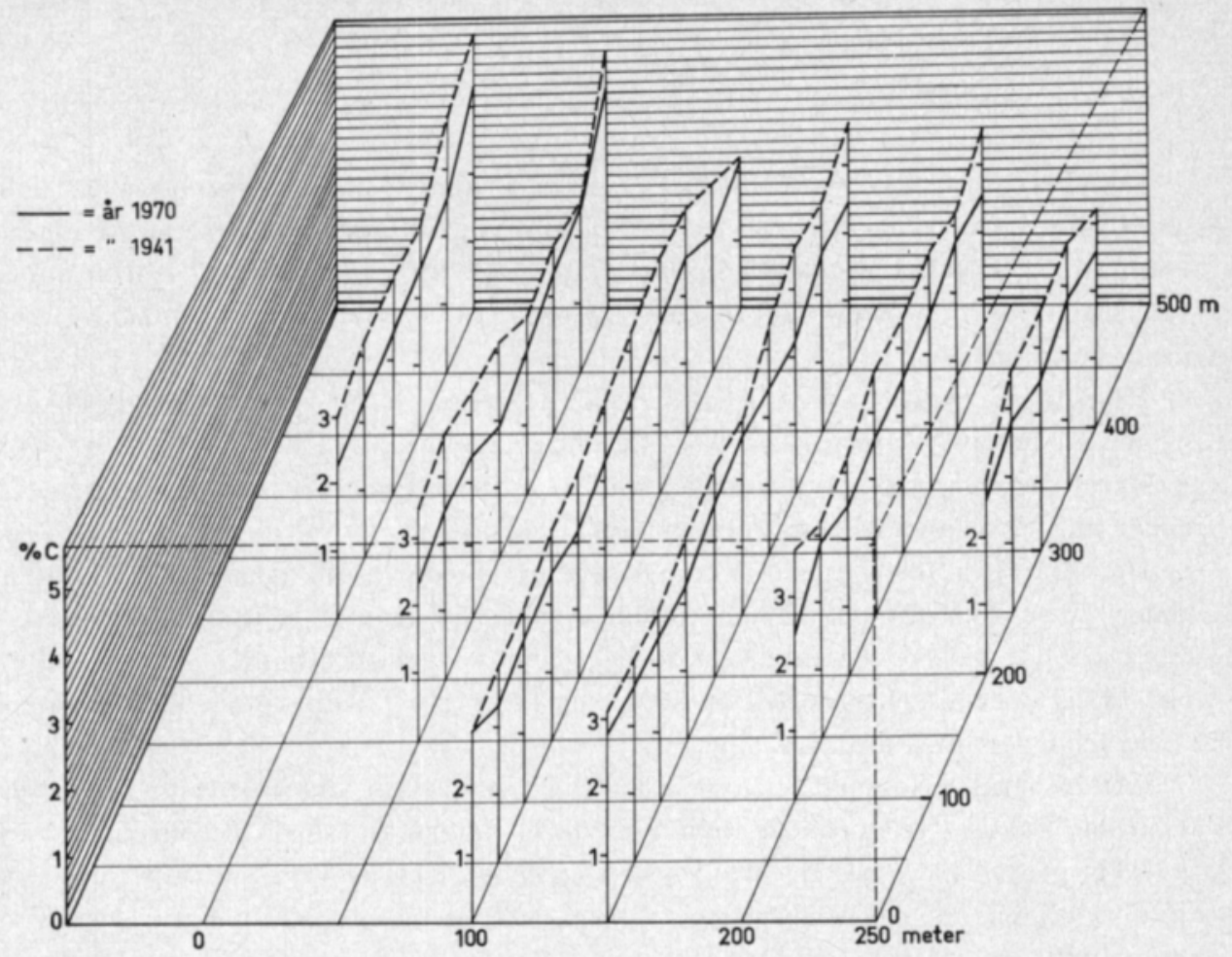

Figur 7. Kolhaltens förändring med tiden i de olika provtagningspunkterna på Hovstallängarna. Fig. 7. Changes of carbon content at the various sampling sites in field Hovstallängarna.

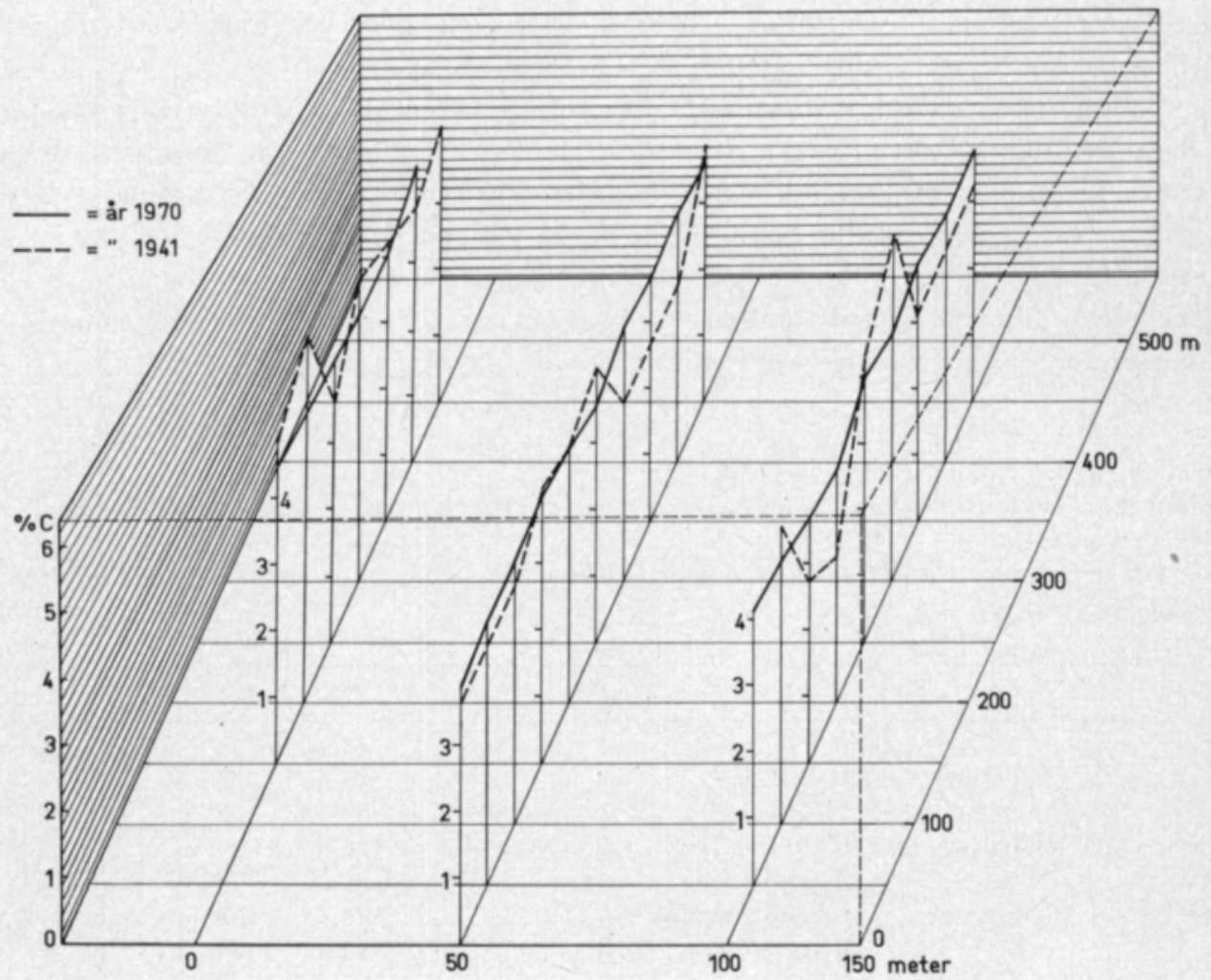

Figur 8. Kolhaltens förändring med tiden i de olika provtagningspunkterna på Reservatet. Fig. 8. Changes of carbon content at the various sampling sites in field Reservatet. 
I Tabell 2 redovisas resultatet av omsättningförsöket. Försöket pågick under 40 dagar och siffrorna avser kolmineraliseringen per $100 \mathrm{~g}$ jord under denna tid. I försöket ingick fyra prover från varje skifte (dock endast tillsammans fyra prover för de båda Hammarbyskiftena). Varje siffra utgör medeltal för dessa fyra prover.

Resultaten visar att mineraliseringen generellt är större för 1941 års prover än för 1970 års prover, att skillnaden mellan 1941 och 1970 års prover är störst för Kungsängenjordarna och att mineraliseringen i Kungsängenjordarna är större än i Ultunajordarna för 1941 års prover.

Det är i och för sig anmärkningsvärt att jordar, som lagrats torrt under nästan 40 år, kan uppvisa så hög biologisk aktivitet utan att ympning företagits. Proverna har visserligen inte lagrats eller behandlats sterilt, men det förefaller föga troligt att aktiviteten till en väsentlig del beror på mikrober, som hamnat i proverna genom kontamination.

Att mineraliseringen är större i 1941 års prover är inget absolut bevis för att dessa prover, vid provtagningen, hade en högre biologisk aktivitet än vad 1970 års prover hade när de provtogs. Den biologiska aktiviteten i ett jordprov ökar nämligen om det torkas och tillföres vatten på nytt. $\mathrm{Nu}$ har visserligen även 1970 års prover torkats, men man kan inte utesluta, att en långvarig torkning kan förstärka effekten. Det faktum att skillnaden mellan provtagningstillfällena är större på Kungsängen än på Ultuna ger emellertid en anvisning om att åtminstone Kungsängenjordarna 1941 hade en högre biologisk aktivitet än 1970. Detta är i överensstämmelse med att humushalten gått ned snabbare på Kungsängen.

Man kan vidare konstatera att Ängen och Hovstallängarna fortfarande har högre biologisk aktivitet än Skifte I, vilket gör att man kan förvänta sig en utveckling mot samma humushalt i de tre skiftena. I överensstämmelse med denna diskussion skulle man förvänta sig en snabbare nedgång i humushalt på Hammarbyskiftena än på Jälbo. På grund av stor heterogenitet med avseende bl.a. på lerhalt mellan och inom dessa skiften är en sådan bedömning emellertid mera vansklig att göra här än på Kungsängen.

Tabell 2. Kolmineraliseringen under 40 dagars inkubation, $\mathrm{mg} \mathrm{C}$ per $100 \mathrm{~g}$ jord. Medeltal för fyra prover.

Table 2. Carbon mineralization after 40 days of incubation, $m g$ per $100 \mathrm{~g}$ soil. Mean of four samples.

\begin{tabular}{|c|c|c|c|}
\hline Gârd & Areal & 1941 & 1970 \\
\hline \multirow[t]{2}{*}{ Ultuna } & Hammarby .. & 114 & 88 \\
\hline & Jälbo ........................... & 84 & 62 \\
\hline \multirow[t]{4}{*}{ Kungsängen } & 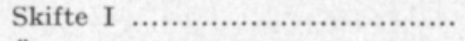 & 118 & 50 \\
\hline & 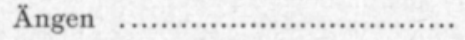 & 136 & 74 \\
\hline & Hovstallängarna ...................... & 128 & 74 \\
\hline & Reservatet ............................ & 242 & 184 \\
\hline
\end{tabular}


Vid Avdelningen för växtnäringslära vid Lantbrukshögskolan har ganska mycket arbete lagts ned på studiet av olika metoder för fraktionering av markens organiska substans (PERsson 1968). Dessa undersökningar har främst tagit sikte på att fastslå vilket värde olika fraktioneringsmetoder har för att beskriva det biologiska skeendet i marken. I undersökningarna studerades hur ${ }^{14} \mathrm{C}$-märkt organiskt materịal fördelar sig på olika fraktioner efter olika omsättningstider.

Den fraktioneringsmetod, som använts i den här aktuella undersökningen och som presenterats under avsnittet "Metodik», omfattar successiv extraktion av jorden varvid behandlingarna blir allt kraftigare. Av tidigare undersökningar framgår att de två första fraktionerna - de som löses ut av $0,5 \mathrm{~N}$ kall $\mathrm{H}_{2} \mathrm{SO}_{4}$ och $0,5 \mathrm{~N}$ varm $\mathrm{H}_{2} \mathrm{SO}_{4}$ - innehåller betydande delar av det mest lättomsättbara materialet. Vidare har den slutsatsen dragits att den största delen av mikrobfloran finns $\mathrm{i}$ den andra fraktionen. De två sista fraktionerna den alkaliresistenta återstoden samt humussyrafraktionen, har ansetts innehålla det mest stabila materialet.

I föreliggande undersökning startades fraktioneringsförsök, dels för àt komplettera kolanalyser och omsättningsförsök, dels för att vinna ytterligare erfarenhet om fraktioneringsmetodens användbarhet för att karakterisera humusförrådet i en jord.

I fraktioneringsförsöket ingick samma jordprover som i omsättningsförsöket, dvs fyra prover från varje skifte. Utrymmet tillåter inte en detaljerad analys av hela det framkomna materialet, men några intressanta resultat skall kommenteras. Därvid kommer endast de fyra ovannämnda fraktionerna - de två första och de två sista - att behandlas. I Tabellerna 3-5 presenteras dessa fraktioner för några av jordproverna. Gruppering av proverna har gjorts med avseende på kolhalt så att Tabellerna 3 och 4 upptar alla prover med

Tabell 3. Innehállet av organiskt kol i nâgra fraktioner av Kungsängenjordar med C-halt $2,0-2,1 \%$, mg C per $100 \mathrm{~g}$ jord.

Table 3. Content of organic carbon in some fractions of Kungsängen soils with $C$ contents of $2,0-2,1 \%$, mg $C$ per $100 \mathrm{~g}$ soil.

\begin{tabular}{|c|c|c|c|c|c|c|c|}
\hline Ar & Skifte & Prov, nr & C-halt & $\begin{array}{l}\text { Utlöst av kall } \\
0,5 \mathrm{~N} \mathrm{H}_{2} \mathrm{SO}_{4}\end{array}$ & $\begin{array}{l}\text { Utlöst av varm } \\
0,5 \mathrm{~N} \mathrm{H}_{2} \mathrm{SO}_{4}\end{array}$ & $\begin{array}{l}\text { Alkalistabil } \\
\text { âterstod }\end{array}$ & $\begin{array}{c}\text { Humussyra- } \\
\text { fraktion }\end{array}$ \\
\hline \multirow[t]{2}{*}{1941} & Skifte I ...... & 10442 & 2.09 & 253 & 620 & 260 & 162 \\
\hline & Skifte I ...... & 10466 & 2.08 & 273 & 654 & 204 & 159 \\
\hline \multirow[t]{6}{*}{1970} & Skifte I ...... & 10440 & 2.09 & 179 & 631 & 240 & 198 \\
\hline & Skifte I ..... & 10466 & 2.09 & 175 & 674 & 221 & 187 \\
\hline & Ängen ....... & 10687 & 2.04 & 185 & 655 & 236 & 183 \\
\hline & Ången ....... & 10743 & 2.09 & 204 & 627 & 244 & 164 \\
\hline & Hovstall- & & & & & & \\
\hline & ängarna ....... & 52 & 2.09 & 120 & 645 & 302 & 178 \\
\hline
\end{tabular}


Tabell 4. Innehâllet av organiskt kol i några fraktioner av Ultunajordar med C-halt 2,0$2,1 \%, \mathrm{mg} \mathrm{C}$ per $100 \mathrm{~g}$ jord.

Table 5. Content of organic carbon in some fractions of Ultuna soils with C contents of $2,0-2,1 \%$. mg $C$ per $100 \mathrm{~g}$ soil.

\begin{tabular}{|c|c|c|c|c|c|c|c|}
\hline Ar & Skifte & $\begin{array}{c}\text { Prov, } \\
\mathrm{nr}\end{array}$ & C-halt & $\begin{array}{l}\text { Utlöst av kall } \\
0,5 \mathrm{~N} \mathrm{H}_{2} \mathrm{SO}_{4}\end{array}$ & $\begin{array}{l}\text { Utlöst av varm } \\
0,5 \mathrm{~N} \mathrm{H}_{2} \mathrm{SO}_{4}\end{array}$ & $\begin{array}{l}\text { Alkalistabil } \\
\text { återstod }\end{array}$ & $\begin{array}{l}\text { Humussyra- } \\
\text { fraktion }\end{array}$ \\
\hline \multirow[t]{4}{*}{1941} & Hammarby $\mathrm{V}$ & 2648 & 2.02 & 152 & 606 & 313 & 212 \\
\hline & Jälbo ............ & 3827 & 2.06 & 146 & 543 & 277 & 327 \\
\hline & Jälbo ........... & 3828 & 2.04 & 156 & 528 & 289 & 340 \\
\hline & Jälbo ............ & 3881 & 2.10 & 139 & 588 & 294 & 269 \\
\hline \multirow[t]{2}{*}{1970} & Hammarby V & 2722 & 2.06 & 177 & 545 & 320 & 214 \\
\hline & Jälbo ............ & 3839 & 2.04 & 97 & 599 & 269 & 324 \\
\hline
\end{tabular}

kolhalt mellan 2,0 och 2,1\% och Tabell 5 några prover med avsevärt högre kolhalt. Provnumren i tabellen hänför sig till de kartor, som ligger till grund för provtagningarna.

Resultaten visar att den första fraktionen - utlöst genom behandling med kall 0,5 $\mathrm{N} \mathrm{H}_{2} \mathrm{SO}_{4}$ - är större för 1941 års än för 1970 års prover. Denna skillnad mellan de båda provtagningarna framgår också tydligt om man studerar hela materialet och därvid jämför proverna punkt för punkt. Iakttagelsen antyder att 1941 års prover innehåller mera lättomsättbart material. Att så också är fallet framgår av omsättningsförsöken, som behandlats i föregående avsnitt. Hur stor del av denna skillnad, som beror på förändringar under lagringstiden kan inte heller utläsas av fraktioneringsförsöken, men eftersom skillnaden mellan provtagningarna är större för Kungsängenjordarna än för Ultunajordarna finns det anledning förmoda att åtminstone en del av skillnaden beror på olika aktivitet vid provtagningarna. Av omsättningsförsöken framgick att mineraliseringen var lägre i Ultunajordarna. Detta återspeglas ganska väl av fraktionens storlek i de olika jordproverna.

I Kungsängenjordarna med kolhalt mellan 2,0 och $2,1 \%$ är överensstämmelsen mycket god mellan de övriga tre fraktionerna vad storleken beträffar (Tabell 3). Detta gäller oberoende av provtagningstillfälle och skifte. Förhållandet gäller för övrigt även för de fraktioner som inte diskuteras här. Vid samma kolhalt har således de tre skiftena i stort sett samma humuskvalitet.

Om man jämför jordar från Kungsängen och Ultuna med samma kolhalt finner man att fraktioneringen gett något olika resultat (Tabellerna 3 och 4). Den första fraktionen har redan diskuterats och vad beträffar den andra och den tredje är skillnaden mellan de båda gårdarna inte stor. Däremot är skillnaden ganska betydande vad gäller humussyrafraktionen, som är större på Ultuna och då i synnerhet $\mathrm{i}$ Jälbojorden. Orsaken till denna skillnad kan vara olikheter i mekanisk sammansättning. Det kan emellertid inte uteslutas att odlingshistorien kan ha haft betydelse för fördelningen av det organiska materialet på de olika fraktionerna. Jordbearbetning och andra kulturåtgärder gynnar oxidationen av organiskt material under bildning av stabila humussubstanser. Eftersom 
Tabell 5. Innehăllet av organiskt kol i några fraktioner av Kungsängenjordar med hög C-halt, $\mathrm{mg} \mathrm{C}$ per $100 \mathrm{~g}$ jord.

Table 5. Content of organic carbon in some fractions of Kungsängen soils with high $C$ contents, mg $C$ per $100 \mathrm{~g}$ soil.

\begin{tabular}{|c|c|c|c|c|c|c|c|}
\hline Àr & Skifte & $\begin{array}{c}\text { Prov, } \\
\mathrm{nr}\end{array}$ & C-halt & $\begin{array}{l}\text { Utlöst av kall } \\
0,5 \mathrm{~N} \mathrm{H}_{2} \mathrm{SO}_{4}\end{array}$ & $\begin{array}{l}\text { Utlöst av varm } \\
0,5 \mathrm{~N} \mathrm{H}_{2} \mathrm{SO}_{4}\end{array}$ & $\begin{array}{l}\text { Alkalistabil } \\
\text { àterstod }\end{array}$ & $\begin{array}{l}\text { Humussyra- } \\
\text { fraktion }\end{array}$ \\
\hline \multirow[t]{3}{*}{1941} & Skifte I ....... & 10496 & 2.86 & 345 & 805 & 321 & 262 \\
\hline & Ången ........ & 10669 & 2.92 & 466 & 884 & 283 & 191 \\
\hline & $\begin{array}{l}\text { Hovstall- } \\
\text { ängarna ....... }\end{array}$ & 37 & 5.58 & 847 & 1437 & 654 & 493 \\
\hline \multirow[t]{3}{*}{1970} & Skifte I ....... & 10496 & 2.75 & 215 & 765 & 341 & 272 \\
\hline & $\begin{array}{l}\text { Ängen ......... } \\
\text { Hovstall- }\end{array}$ & 10669 & 2.71 & 301 & 849 & 303 & 221 \\
\hline & ängarna ....... & 37 & 4.09 & 417 & 1085 & 520 & 409 \\
\hline
\end{tabular}

Ultunajordarna varit i odling mycket längre än Kungsängenjordarna har humusbildningen under gynnsamma betingelser kunnat fortgå mycket längre där. En annan företeelse, som helt eller delvis, kan förklara olikheterna i humussyrafraktionerna är kalktillståndet. Det är välkänt att oxidationsgraden hos den organiska substansen är högre på jordar med gott kalktillstånd. Ultuna har ett naturligt högt $\mathrm{pH}$-värde. Även på de delar, där glacialleran inte går i dagen ligger pH-värdet nära neutralpunkten. På Kungsängen är däremot jordarna av naturen sura. De har visserligen kalkats så att pH-värdet numera är hyggligt, men detta har gjorts ganska sent.

Slutligen skall jämförelse göras mellan jordar med hög och låg kolhalt. En jämförelse av siffermaterialet i Tabellerna 3 och 5 visar att storleken av samtliga fraktioner ökar med totalhalten och ökningen är proportionsvis ungefär lika stor för alla fraktioner. Om humushalten sjunker på grund av mineralisering kan man således förvänta sig att samtliga fraktioner minskar i storlek - även de som representerar det mera stabila organiska materialet. Kolanalyserna i denna undersökning har visat att minskningen i kolhalt på grund av mineralisering under vissa omständigheter kan vara mycket stor. På sådana jordar kan man således förvänta sig att storleken av återstod och humussyrafraktion kan minska avsevärt under loppet av 30-40 år. De båda fraktionerna innehåller således inte enbart det extremt stabila material, som man förknippar med egentliga humussubstanser, vilka kan bli åtskilliga hundra år gamla.

\section{Sammanfattande diskussion}

Föreliggande undersökning över odlingsåtgärdernas inflytande på humushalten har kunnat genomföras tack vare att jordprover och provtagningskartor från en markkarteringsundersökning på 1930-talet finns bevarade. Provtagningen har upprepats i början av 1970-talet och jordprover från de båda provtagningarna har analyserats. Olika omständigheter gör att försöksmaterialet 
får anses som unikt. Således finns, på de undersökta egendomarna, jordar av olika ursprung och sammansättning. Vidare representerar olika delar helt olika odlingshistoria, som är ganska väl känd. Vissa skiften har' en mycket gammal odlingshistoria medan andra inte varit uppodlade mer än ungefär 100 år ett mindre område har t.o.m. aldrig odlats.

De resultat, som framkommit i undersökningen måste emellertid omgärdas med vissa reservationer och viktigast härvidlag är den effekt på humushalten som en förändring i plöjningsdjupet kan ha. En ökning av plöjningsdjupet gör att matjorden spädes ut med humusfattig alv, vilket betyder att humushalten sjunker även om ingen nettomineralisering ägt rum. Om en sänkning av humushalten skett från det ena provtagningstillfället till det andra kan detta således helt eller delvis bero på att plöjningsdjupet ökats någon gång under tiden mellan provtagningarna. I det framkomna materialet finns emellertid vissa fakta, som tyder på att förändringar i plöjningsdjupet inte haft någon avgörande inverkan på resultaten.

Osäkerhet vid tolkningen av resultaten skapas också av att man inte vet om några förändringar ägt rum i de prover, som lagrats sedan första provtagningen. Kolhalten torde knappast ha förändrats under lagringen. Däremot kan man inte utesluta att vissa förändringar kan ha skett i den organiska substansens sammansättning. Detta kan påverka omsättningsförsöken och fraktioneringsförsöken. Resultaten från dessa försök visar att det föreligger skillnad mellan prover från de båda provtagnigstillfällena vad gäller det mest lättomsättbara materialet, men det framgår också av resultaten att denna skillnad inte helt kan tillskrivas förändringar, som skett under lagringen.

Undersökningen visar att betydande humushaltsminskningar har skett på Kungsängen under de ca 40 år, som ligger mellan provtagningarna. Denna gård, som uppodlats först efter år 1850, representerar unga odlingsjordar. Under årtiondena närmast efter uppodlingen har humushaltsminskningen varit mycket betydande. Senare har den avtagit utan att för den skull upphöra. Den snabba nedgången i humushalt får anses bero på att humushalten ännu inte stabiliserat sig vid något jämviktsläge.

Inte enbart tidsperiodens längd efter uppodlingen, utan även fuktighetsförhållandena har påverkat storleken av humushaltsförändringen.

Även på Ultuna, som representerar gammal odlingsmark, kan man konstatera att humushalten sjunkit på vissa arealer, och denna minskning kan förmodligen inte helt tillskrivas förändringar i plöjningsdjupet. Anledningen till att det har skett en nettominskning av humusförrådet är förmodligen främst att söka i en intensifierad jordbearbetning. Växtodlingen kan nämligen inte betraktas som rovdriftsbetonad - vallandelen har varit ganska hög. Man kan emellertid inte bortse från möjligheten av att förändring av fuktighetsförhållandena påverkat situationen. Under senare hälften av 1800-talet dränerades Ultuna och denna åtgärd har helt säkert påverkat humusbalansen. Det kan inte anses som osannolikt att jämviktsinställelsen av humushalten pågått några tiotal år in på 1900-talet.

Undersökningen har kunnat genomföras tack vare ekonomiskt understöd frân Statens Råd för Skogs- och Jordbruksforskning. 


\section{LITTERATUR}

HeBbe, P. 1936. Några blad ur Ultunas äldsta historia. Kungl. Landtbr.akademiens HandI. och Tidskr., häfte 5: 1-23.

Jansson, S. L. \& ValdmaA, K. 1961. Determination of carbon in soil by dry and wet combustion. Kungl. Lantbr.hōgsk. Ann. 27: 305-322.

Lantbrukshögskolan, En vägledning. 1938.

Persson, J. 1968. Biological testing of chemical humus analysis. Lantbr.högsk. Ann. 34: 81217.

— - - 1972. Metodik för humusanalys i fältförsök. Grundförbättring 25, 4: 165-172.

Sernander, R. 1948. Uppsala Kungsäng.

Torstensson, G. \& Eriksson, S. 1941. Agronomiska kartor ôver Ultuna egendom jämte beskrivning.

Ultuna Lantbruksinstitut 1848-1898. 